\title{
EDITORIAL
}

Gary R. Saxonhouse $\cdot$ Robert M. Stern

\section{Reversal of fortune: Macroeconomic policy, international finance, and banking in Japan}

Published online: 29 November 2005

(C) Springer-Verlag 2005

\begin{abstract}
This essay provides an introduction and overview for a symposium on macroeconomic policy, international finance and banking in Japan. The symposium consists of thirteen papers. Nine of the papers including most of those on macroeconomic policy and international finance appear in this issue. The remaining papers including one on macroeconomic relations within the Asia-Pacific region and three on Japan's banking system will appear in a special section of the next issue of this journal.
\end{abstract}

\section{Introduction}

During the past 50 years no major, industrialized, high-income country has suffered a more remarkable reversal of economic fortune than has Japan since 1989. Japan's potential per capita real rate of GDP growth which was viewed as 4\% during the 1980 s is now seen as a little better than $1-1 / 2 \%$ (OECD 2005). The Bank of Japan once seen as sure footed model for central banks for having insulated Japan from economic impact of the 1979 Iranian Revolution and the 1987 equity markets meltdown is now viewed as clumsy (Ito 1992; Ahearne et al. 2002). In the most stunning reversal of perception of all, Japan's banks once viewed as skilled practitioners of relationship banking are widely viewed today as artifacts of bygone era of protective regulation. Their future role as financial intermediaries in the Japan of tomorrow remains unclear.

The papers in this Symposium seek to shed new light on this reversal of Japan's economic fortunes even as they also make new proposals to speed Japan's recovery. ${ }^{1}$

G. R. Saxonhouse $(\bowtie) \cdot R$. M. Stern

University of Michigan, Ann Arbor, USA

${ }^{1}$ These papers were originally presented at a pre-conference meeting in Tokyo in May 2004 and in a conference at the University of Michigan in October 2004. The program of research was sponsored jointly by the University of Michigan and the Hitotsubashi University. Funding was provided by the Japan Foundation, Center for Global Partnership, the Economic and Social Research Institute, Cabinet Office, Japan, the Center for Japanese Studies of the University of Michigan, and the 21st Century COE Program, Research Unit for Statistical Analysis in the Social Sciences, Hitotsubashi University. 


\section{Macroeconomic policy}

\subsection{The disconnect between professional economists and policy-making in Japan}

In their paper, "The Role of Preconceived Ideas in Macroeconomic Policy: Japan's Experience in Two deflationary Periods," Koichi Hamada and Asahi Noguchi take pains to point out that the past 15 years is not the only time in the past 100 years that Japan has suffered severe peace-time economic difficulty. The years immediately after the First World War and the 1920s were also difficult times for Japan. Hamada and Noguchi see a link between the two periods. In both periods policy makers and the public had a basic misunderstanding of the source of the problems facing the Japanese economy and the steps needed to promote Japan's recovery. Sadly, in each case, many professional economists correctly diagnosed Japan's situation, but were unable to influence the policy process.

In the 1920s, Japan's policy makers, Japan's newspapers, the Japanese public, and even Japan's academic economists believed that a return to the gold standard at the pre-World War I parity would restore strength to the economy. Only private sector economists, such as Kamekichi Takahashi and Tanzan Ishibashi, fully appreciated the costs Japan might face if it attempted the deflation of prices and wages required for a return to the pre-war regime. It was only after Japan experienced much of these costs that policy makers were willing to change course.

According to Hamada and Noguchi, the roles policy makers, newspapers and professional economists have played in the most recent policy debate on deflation is very similar to what occurred 80 years ago. Once again, policy makers, newspapers and the public were for many years very tolerant of deflation. Deflation was seen as a necessary by-product of structural adjustment. For many, the more deflation, the more evidence that progress was being made on the road to economic recovery. Once again, economists, this time among them many academic economists, stood apart from this consensus. Viewing deflation as a monetary phenomenon, they called on the Bank of Japan to adopt a highly expansionary monetary policy so that Japan's economic recovery might commence. As in 1920s, in Hamada's and Noguchi's view it was only after Japan had experienced a long period of unnecessary stagnation that both the policy makers and the public changed their outlook and expansionary monetary policy commenced.

Hamada and Noguchi are at pains to emphasize that it was not self-interest that caused policy makers and the press to champion diagnoses and policies that they later learned were wrong. Rather, economists had difficulty in mobilizing support for steps that ultimately proved to be entirely correct. It is possible that changes in the government's economic policy-making institutions (the creation of the Council of Economic and Financial Policy in the Cabinet Office in 2001) that make it easier for academic economists to participate in the critical discussions that shape policy may make this less a problem in the future.

\subsection{Price expectations and monetary policy}

Changing price expectations are one channel through which an expansionary monetary policy belatedly promoted by the Bank of Japan can fight deflation. Despite its potential importance, however, there has been relatively little research 
in Japan on the determinants of price expectations. Hori and Shimizutani in their paper, "Price Expectations of Japanese Household: Evidence from Original Survey Data" take advantage of an original household-level data set to examine the factors that affect price expectations, and explore how changes in price expectations can affect household consumption. Their study confirms that deflationary expectations discourage household consumption. At the same time, it seems clear that the Bank of Japan's repeated announcements of an easing of monetary policy did little to change household price expectations. Only $5 \%$ to $10 \%$ of the households in the Kokumin Seikatsu Monitor data set revised upwards their price expectations in response. This certainly suggests that the expansionary Japanese monetary policy advocated by Hamada and Noguchi labors under special handicaps.

\subsection{A role for fiscal policy?}

Hamada and Noguchi stress that there is a consensus among Japanese economists that monetary policy is the key to Japanese recovery. While, as will be seen, there are certainly exceptions to this view in Japan, in the United States quite a number of influential economists have taken the position that expansionary fiscal policy also has a role to play (Kuttner and Posen 2001; Hubbard 2002; Borda and Weinstein 2004). Ihori and Nakamoto in "Japan's Fiscal Policy and Fiscal Reconstruction" take exception to this view. Extending their earlier VAR analysis with more recent data, they find no evidence that an increase in public investment or a tax cut has much of expansionary impact. ${ }^{2}$ Indeed, in the 1990s some crowding out of a private investment is observed. In addition, there seems to be some evidence, given Japan's massive deficit and large outstanding public debt, that fiscal tightening, rather than undermining aggregate demand, led to an increase in consumption, though the magnitude is small.

While Ihori and Nakazato reject any role for expansionary fiscal policy, unlike Hamada and Noguchi, they do see deregulation and structural adjustment, and with it decline in prices in particular goods and services, as capable of promoting Japanese recovery. Indeed, they find deregulation capable of having a substantially greater macroeconomic impact than fiscal policy.

\subsection{Gesell Taxes and Eisler Taxes}

An expansionary monetary policy may be necessary to promote the Japanese recovery, but it is possible such policies may not be sufficient. In the presence of deflation, the inability to push nominal interest rates below zero may leave real interest rates too high at this stage of Japan's business cycle to call forth the rate of investment required to assure a return of Japan to full employment. Mitsuhiro Fukao in "The Effects of 'Gesell' (Currency) Taxes in Promoting Japan's Economy" proposes a number of measures to cope with this problem. In particular, he argues that the Bank of Japan should raise its price level target from zero to $1.4 \%$ per annum as measured by the core consumer price index with a margin of error of plus or minus

\footnotetext{
${ }^{2}$ See Saxonhouse and Stern (2003) for a comparison of Kuttner and Posen (2000) with Ihori et al. (2003).
} 
$1 \%$ over a three-year horizon. To achieve this end, the Bank of Japan should buy large amount of market-indexed ETFs (Exchange Traded Funds) and marketindexed REITs (Real Estate Investment Trusts). If this measure is not effective, the government should break the nominal interest rate floor by levying a tax on all government guaranteed financial assets including currency.

Willem Buiter provides a somewhat different view in "Overcoming the Zero Bound on Nominal Interest Rate: Gesell's Currency Carry Tax vs. Eisler's Parallel Virtual Currency." He notes that despite the zero lower bound on the short-term rate in Japan having become a binding constraint, conventional monetary policy in the form of generalized open-market purchases of government securities of all maturities has not been pushed to the limit where all outstanding government debt and all current and future government deficits are or are confidently expected to be monetized. As long as the risk-free nominal interest on financial instruments of any maturity remains positive, a currency tax, in Buiter's view is unwarranted.

Unlike Buiter, Fukao does not think that the massive open-market purchases of long-term bonds is feasible. If the Bank of Japan holds a massive amount of longterm JGBs when long-time interest rates rise it will experience a very large capital loss. At the very time it is experiencing this loss, it will also be necessary for it to raise short-term interest rates by mopping up excess liquidity. Fukao believes that before it will be able to accomplish this completely the Bank of Japan will run out of assets to sell. If it is to continue with its open-market operation it will be forced to issue interest-bearing promissory notes. According to Fukao, this will result in the Bank of Japan being forced to turn to the government for a subsidy.

In contrast, not only does Buiter feel charging negative interest on money is unnecessary, he worries that it will be administratively difficult. The original proposal made by Silvio Gesell that currency be stamped to indicate that it is current on interest rates is feasible, but Buiter feels it will be costly and intrusive, and, therefore, should only be used as a last resort. Buiter notes that a proposal made by Robert Eisler in 1932 overcomes the problems of both cost and intrusiveness by unbundling the medium of exchange/means of payments function from the numeraire function of money through the creation of a parallel, virtual money. By controlling the exchange rate between the means of payment and the numeraire, specifically by appreciating the value of the currency in terms of the numeraire, monetary authorities such as the Bank of Japan, can achieve a negative interest rate on the numeraire even though the interest rate on currency remains constrained by the lower bound.

Eisler's proposal raises the fundamental issue about who chooses or what determines the numeraire used in private wage and price contracts. According to Buiter, Eisler's implicit assumption that monetary authorities can credibly determine the numeraire used in private wage and price contracts is shaky both a priori and empirically. What might otherwise be a neat solution to a difficult problem remains suspect.

\subsection{Supply shocks and Japanese deflation}

As noted, Hamada and Noguchi, in their paper for this Symposium, dismiss the role of positive supply shocks as a cause of Japan's deflation. Indeed, they attribute the long delay in Japan's recovery to the mistaken view that Japan's deflation reflects 
an acceleration of technological progress. In his contribution to this Symposium, "Good Deflation/Bad Deflation and Japanese Economic Recovery," Saxonhouse, following Bordo et al. (2004), notes that, whatever the current situation in Japan, economic history certainly suggests that technological progress can go hand in hand with general deflation. Conducting a VAR analysis using very detailed information about the components of Japan's consumer price index, Saxonhouse finds that short-run shocks to Japan's relative price structure persist in the long run. Given this finding, he concludes that such shocks are real in origin and reflect technological change. As no effort has yet been completed to show the full extent to which technological change is driving short-run relative price change in Japan compared with other factors, and the full extent to which relative price changes are driving aggregate price change compared with other factors, the policy implications of Saxonhouse's findings are unclear. Nevertheless, they may provide some support for Ihori's and Nakamoto's view on the relationship between deregulation and macroeconomic improvement. What is clear, however, is that it is a mistake to dismiss out of hand the possibility that technological shocks are playing an important role among other forces in Japan's current deflation.

\section{Macroeconomic policy and the exchange rate}

\subsection{Intervention policy and exchange rate changes}

In the debate over whether non-standard monetary policies, such as those discussed by Mitsuhiro Fukao and Buiter are needed, it is sometimes forgotten that unsterilized exchange rate intervention remains a monetary tool that can be used to stimulate the Japanese economy (Svensson 2001, 2003). Takatoshi Ito's paper, "Interventions and Japanese Economic Recovery" and Rasmus Fatum's and Michael Hutchison's paper, "Foreign Exchange Rate Intervention and Monetary Policy in Japan, 2003-04," both examine the rationale behind the massive increase in foreign exchange market intervention in 2003-2004 and evaluate its effectiveness in promoting an external value of the yen and a change in the money supply capable of supporting Japanese economic recovery. Using different approaches, both papers document the dramatic change in intervention that commenced in Japan in January 2003 and continued until March 2003. During these 14 months 3.5 trillion yen ( $7 \%$ of GDP) in interventions were conducted. Unlike interventions conducted in the preceding six years when Eisuke Sakakibara and Haruhiko Kuroda were Vice Ministers for International Finance at the Ministry of Finance, these interventions were both frequent and unannounced. While agreeing on the outline of the changes in policy, Ito and Fatum-Hutchinson disagree to as to whether intervention policy was effective in preventing the yen appreciation that a fragile Japanese economy battling deflation could ill afford. Ito estimates a reaction function explaining Japanese intervention. He finds that the unannounced interventions in 2003-2004 might have been larger because they were not as effective yen-for-yen as the announced intervention during the Sakakibara-Kuroda period. Nevertheless, by selling 3.5 trillion yen Ito finds that the Japanese authorities achieved a yen-dollar range from 105 to 115 in Spring-Summer 2004, instead of the range 90 to 100 that he feels would otherwise have prevailed. In other words, Ito finds that a $13.3 \%$ depreciation was achieved by "leaning against" the 
market when the yen was appreciating, and "leaning in" the market when the yen was depreciating.

While agreeing with Ito that intervention was effective during the SakakibaraKuroda period, Fatum and Hutchison find the massive interventions of 2003 ineffective and the massive interventions of early 2004 actually pushing the yen in the wrong direction. Fatum and Hutchison suggest that other studies of exchange rate intervention by Japanese monetary authorities have found different results possibly because they are contaminated by sample selection bias. Intervention typically occurs during periods of abnormal exchange rate movements and not when normal exchange rate market conditions prevail. To get around this problem they match-up cases where economic circumstances were in every regard the same except that in one case intervention occurred and in the other it did not. It is from an analysis of these cases that Fatum and Hutchison draw their conclusions about the effectiveness of intervention policy.

Fatum and Hutchison also explore the hypothesis that the reduced effectiveness of the intervention over the 2003-2004 period compared with the SakakibaraKuroda period is related to the degree of sterilization. Did increased sterilization mean a decline in the effectiveness of intervention? Interventions carried out by the Bank of Japan on behalf of the Ministry of Finance are automatically sterilized since the Ministry of Finance must first raise the necessary funds for foreign exchange purchases by selling yen-denominated bills in the domestic market. The real question is what action, if any, does the Bank of Japan take to unsterilize the intervention? Fatum and Hutchison find that the Bank of Japan has not allowed Ministry of Finance interventions to influence the day-to-day conduct of monetary policy. In addition, they find no evidence that the Bank of Japan responded to intervention action by the Ministry of Finance in 2003-2004 by increasing base money at a rate faster than it might otherwise have done. Indeed, cumulative foreign currency purchases by the Ministry of Finance were more than twice as large as the increases in base money engineered by the Bank of Japan. The Bank of Japan on its own was attempting to stimulate the economy in 2003-2004 through rapid base-money growth, but this does not seem to have been influenced by the exchange rate intervention policy of the Ministry of Finance. Much of this intervention remained sterilized, in Fatum's and Hutchinson's view, perhaps accounting for its lack of effectiveness.

\subsection{Exchange rate change and economic performance}

Unlike Ito, Ronald McKinnon rejects the use of exchange rate change as a tool for economic adjustment. In "Exchange Rate or Wage Changes in International Adjustment? Japan and China versus the United States," he notes American-sponsored exchange rate adjustment has wreaked havoc with the Japanese economy in the past, and will do so again in China and Japan today if they succumb today to US pressure. McKinnon believes US government officials are mistaken if they believe exchange rate adjustment will significantly alter international economic imbalances. A yen or renminbi appreciation will raise the price of Japanese or Chinese goods and services relative to foreign goods and services, discouraging their purchases, but the appreciation also has a deflationary impact because of the loss in value of the dollar assets each of these countries hold. As a result, the net impact of 
an appreciation is indeterminant. In McKinnon's view the history of US-Japanese economic relations over the past 30 years makes very clear that yen appreciation did not have any lasting impact on the structural surplus in Japan's international accounts. At the same time, this appreciation imposed a deflationary bias on monetary policy ultimately pushing Japan into a liquidity trap from which it has yet to emerge. New demands emanating from the United States that Japan further appreciate the yen even while it is continuing to experience deflation make little sense to McKinnon. Moreover, he fears that intense US pressure now to break of the peg between the renminbi and the dollar will push China down the same unhappy path that Japan has gone.

In preference to using exchange rate changes to mitigate international economic imbalances, McKinnon believes that not only the renminbi but all currencies in East Asia, including the yen, should be pegged to the dollar. If each country's monetary policy permits nominal wage growth to reflect increases in productivity, international adjustment will take care of itself far more readily than is the case under today's ad hoc regime.

\subsection{Monetary regimes and stabilization policy}

While McKinnon argues for the superiority of the dollar peg system on medium and long-term grounds, the model constructed by Koichi Kamada and Izumi Takagawa in their paper, "Deepening Interdependence in the Asian-Pacific Region: An Empirical Study Using a Macro-Econometric Model" is able to test a dollar peg system versus other regimes over shorter-time horizons. Insofar as coping with economic crises are concerned, Kamada and Takagawa find that a currency-basket regime is clearly superior to both the dollar-peg system advocated by McKinnon as well as the current ad hoc regime. This is true for China and Japan, as well as for most other countries in East Asia. At least on short-run stabilization policy grounds, a regime where all countries peg their currencies to the dollar is worse for many countries in East Asia, not only compared to a regime where all countries peg to a currency basket, but also to the present regime.

\section{Banking, structural adjustment and Japanese economic performance}

\subsection{Government policy and the banking system}

Even if the Bank of Japan had pursued a highly expansionary money policy in the mid and late 1990s it is by no means that a recovery of the Japanese economy would have ensued. By that time the balance sheets of Japanese banks had deteriorated to such an extent that the conventional monetary transmission system had broken down (Bernanke 2000). If banks will not lend simply increasing a supply of base money will do little to stimulate the economy. In his paper, "Reform of the Japanese Banking System," Kawai investigates how Japanese banks ceased to be effective financial intermediaries and the role that government policy has played in the banking sector's distress and slow recovery.

The asset-price bubble in the late 1980s and its subsequent collapse were largely responsible for the emergence of non-performing loans (NPLs) and the 
banking sector problem. Nevertheless, the situation was exacerbated, Kawai argues, by the absence of a tradition of assessing and pricing the risks of lending to particular borrowers. This was an important factor in the over-extension of collateral-based but risky loans. And the entire problem was made even worse by the banks operating within a very weak prudential and supervisory framework.

Kawai finds that the absence of a comprehensive strategy addressing the banking sector problem when it first emerged was clearly a mistake that allowed a systemic banking crisis to emerge in 1997-1998 to be followed by a large output loss during 1998-2002. Japan's financial authorities underestimated the nature and seriousness of the problem, had unwarranted expectations of renewed growth that they hoped would restore asset values and bank balance sheets, and continued fiscal expansion to support aggregate demand allowing insolvent banks to survive thereby delaying resolution of the problem.

The 1997-1998 crisis did prompt the government to take more aggressive and decisive measures. Kawai notes that there has been some progress on banking sector restructuring through the closing or temporary nationalization of non-viable banks, tighter loan classification and loan provisioning, and the acceleration of NPL disposal. The worst may be over, but there remain significant risks concentrated in regional and smaller banks that are vulnerable to weak local conditions, persistent deflation, and increases in the long-term interest rate.

\subsection{What role for Japan's Banks}

The regulatory framework that was in place for much of the second half of the last century in Japan put the banking system at the center of resource allocation. Kyoji Fukao, Kiyohiko G. Nishimura, Qing-Yuan Sui and Masayo Tomiyama in their paper "Japanese Bank Monitoring Activities and the Performance of Borrower Firms 1981-1996" attempt to assess empirically the contributions made by Japanese banks. They find that after 1981, following widespread organizational changes, both the resources devoted to and the quality of what bank monitoring was done declined. While there remained a positive association between bank monitoring and firm profitability, this was mostly due to the banks choosing the most profitable loan applicants rather than because banks in any significant way provided advice that enhanced the profitability of their borrowers. It is a measure of the current low esteem in which banks are held that even the result that they are able to successfully screen loan applicants seems surprising and is at variance with the conclusions drawn by Kawai. Even so, if Japanese banks are to play an important role in Japan's economy in the future they will in all likelihood need to have a monitoring function that does provide value-added to their borrowers.

This last point is underlined by the results in the paper by Alan Ahearne and Naoki Shinada, "Zombie Firms and Economic Stagnation in Japan". Zombie firms are debt-ridden companies that, despite their dismal performance, continue to receive financial support from borrowers who at some earlier time viewed them as safe, profitable borrowers. Measured productivity growth of these firms has tended to be well below the average for the rest of the economy, or even negative, putting a significant drag on the productivity performance of the Japanese economy as a whole. Worse, Ahearne and Shinada find that in the construction, wholesale, and retailing sectors where there are large concentrations of zombie firms the 
reallocation of resources is going perversely from productive to unproductive firms. The continuing support of these zombie firms by Japan's banks is an important factor in the banking sector's poor performance. Ahearne and Shinada argue that banks should be provided with incentives to withdraw their support, and force firms to meaningfully restructure or, in some cases, to close.

\section{Some difficulties posed by recovery}

Japan is once again in the midst of a fragile recovery as it has been on at least in five other occasions in the past 15 years. This latest recovery is somewhat different from some of those in the recent past because, notwithstanding continuing deflation, it is being driven by domestic consumption and non-residential private investment, and not only by exports. Even so, Japan's sustained escape from economic stagnation is fraught with difficulties. As the papers in this Symposium discuss in detail macroeconomic policy, international finance, and the banking system, individually and together, pose major problems for the future of Japan's economy.

The very large volume of outstanding government debt as a proportion of GDP makes it likely that as the Japanese economy attempts a sustained recovery, longterm interest rates on government debt will rise. The most immediate impact of this rise in interest rates will be on the Japanese banking system's balance sheet. Japanese banks have returned to profitability and the nominal value of their outstanding NPLs is declining. Nevertheless, there continues to be a contraction in bank lending (OECD 2005). In consequence, Japanese government debt continues to be an important part of the banking sector's assets. As noted by both Kawai and Mitsuhiro Fukao, a rise in interest rates will impose a significant capital loss on the Japanese banking system. What has been gained after long effort from the writing off of NPLs, the unraveling of cross-holding equity relationships between borrower and lender, and the infusion of government capital may be quickly lost. ${ }^{3}$

The likely rise in long-term interest rates will do more than just pose difficulties for the banking system. Because of the government's very large outstanding debt, the rise in rates not only reflects, but also reinforces public concern about the sustainability of Japan's fiscal position. At the very time that new government expenditures might be needed to shore up the banking system, however, the imperatives of public finance require, as Ihori observes, a continuing paring of expenditures and a raising of revenues.

The likely rise in interest rates will complicate Japan's recovery on yet a third front. Rising rates in Japan will put still further pressure on the yen to appreciate. If Ito is correct, the Ministry of Finance has the tools to cope with this problem, but McKinnon suggests that in the face of American counter-pressure, the political will to intervene cannot always be counted upon. Fatum's and Hutchison's findings, however, imply that even if the political will is there a good outcome is not assured.

The difficulties just outlined can be mitigated by continued, credible government steps towards fiscal consolidation that aims, as Ihori suggests, at the

\footnotetext{
${ }^{3}$ Saxonhouse and Stern (2003) discuss how the US Treasury and the Board of Governors of the Federal Reserve System dealt with a similar problem in the 1940s and what lessons Japan might learn from this experience.
} 
elimination of Japan's primary government deficit, and the creation of a modest surplus. In an environment of less than robust aggregate demand must be skillfully managed lest Japan once again slip into a recession. ${ }^{4}$

\section{References}

Ahearne A et al (2002) Preventing deflation: lessons from Japan's experience in the 1990s. Board of Governors of the Federal Reserve System, International Finance Discussion Paper, No. 729 (June)

Bernanke BS (2000) Japanese monetary policy: a case of self-induced paralysis? In: Mikitani R, Posen AS (eds) Japan's Financial Crisis and Its Parallels to US Experience. Institute for International Economics, Washington, District of Columbia

Borda C, Weinstein D (2004) Happy news from the dismal science: reassessing Japanese fiscal policy and sustainability. Columbia University Center on Japanese Economy and Business Working Paper, No. 228

Bordo M, Lane JL, Redish A (2004) Good versus bad deflation: lessons from the gold standard era. NBER Working Paper, No. 18239

Hubbard RG (2002) Impediments to growth in Japan (Speech before the Japan Information Access Symposium: Washington, District of Columbia, April 8)

Ihori T, Nakazato T, Kawade M (2003) Japan's fiscal policies in the 1990s. World Econ 26:325-338

Ito T (1992) The Japanese Economy. MIT, Cambridge, Massachusetts

Kuttner KN, Posen AS (2001) The great recession: lessons for macroeconomic policy from Japan. Brookings Papers in Economic Activity, 93-185

Organization for Economic Co-operation and Development (2005) Economic survey: Japan, Paris

Saxonhouse GR, Stern RM (2003) The bubble and the lost decade. World Econ 26:267-282

Svensson LEO (2001) The zero-bound in an open economy: a fool-proof way of escaping the liquidity trap. Monet Econ Stud 19:277-321

Svensson LEO (2003) Escaping from the liquidity trap and deflation: the fool-proof way and others. J Econ Perspect 17:145-166

${ }^{4}$ Saxonhouse and Stern (2003) discuss different proposals for introducing consumption tax increases in ways that would encourage rather than frustrate short-run recovery. 